\title{
THE ESTABLISHMENT OF KINGDOMS AND THE IDENTIFICATION OF KINGS AND QUEENS IN TERMS OF THE TRADITIONAL LEADERSHIP AND GOVERNANCE FRAMEWORK ACT 41 OF 2003
}

JC Bekker*

\section{Introduction}

The object of this article is to evaluate the mechanisms created by the Traditional Leadership and Governance Framework Act 41 of $2003^{1}$ to decide on traditional leadership disputes and claims. There are many claims and disputes, but this article will focus on the newly-created positions of kings and queens.

\section{Position of Kings and Queens under the Traditional Leadership and Governance Act}

The process of identifying these kings and queens is on closer examination beset with uncertainties that go deeper than merely resolving claims and disputes. It is submitted that the criteria set out in section 9 of the Act leave the door wide open for discretionary application.

In one of its efforts to eliminate all of the real or perceived wrongs of colonialism and apartheid, the post-apartheid government decided to redesign traditional leadership positions. The reason was that -

In the main, according to custom, three levels of traditional leadership positions are recognised, namely kingship, chieftainship and headmanship. However, colonial powers and the apartheid government introduced new and foreign levels of traditional leaders.

* Honorary Professor in Private Law, University of Pretoria.

1 Traditional Leadership and Governance Framework Act 41 of 2003, hereinafter 'the Act'. 
The introduction of such levels within the institution of traditional leadership was, in many instances, politically motivated and included levels such as 'supreme chief', 'paramount chief', 'subchief', and 'independent headmen'. For example, the level of a 'supreme chief' was introduced by the previous regime to arrogate the power to rule over Africans to the Governor-General and, later, the State President. Other levels such as paramount chiefs, independent headmen and subchiefs were introduced to elevate/demote certain people to new positions. $^{2}$

After deliberations it was decided to create only three positions, namely kingship, senior traditional leadership, and headmanship. ${ }^{3}$

There is ample evidence that the colonists were well aware of the existence of kings in their African colonies. This is how Sansom ${ }^{4}$ described it:

Historical developments in Africa allow definition of three grades of polity. In ascending order these were: independent chiefdoms, federations of chiefdoms and, finally, kingdoms in which erstwhile chiefdoms became districts. Federations and kingdoms grew out of independent chiefdoms and used the chiefdom as a constituent part of the enlarged polity.

This is probably what the legislature had in mind when creating a kingship by saying no more than that it means "the position held by a king or queen". 5

I pause to say that there is no provision for the creation of new kingships neither criteria nor a procedure. Section 9(1)(b) of the Act provides merely that when the position of a king or a queen is to be filled the President must recognise a person taking into account "whether a recognised kingship exists". 6

On the face of it anybody who falls within the broad categorisation of Sansom above, could come forward and say he or she should be recognised. Section 25(2)(a)(i) purports to narrow the claims down to cases where there is doubt

2 DPLG Role of Traditional Leaders 19.

3 S 8 of the Traditional Leadership and Governance Framework Act 41 of 2003, hereafter 'the Act'.

4 Sansom Traditional Leaders and their Realms 248.

5 S 1 of the Act.

6 My emphasis. 
whether a kingship was or was not established, ostensibly indicating that parliament's purpose was the auditing of existing kingships and their incumbents. In practice there are other traditional communities that claim to be kingships. Judged by the large number of senior traditional leaders (formerly chiefs, of course), a number of about $773,{ }^{7}$ this could result in a substantial number of claims. The claimant has to prove only that -

(a) there are substantial (whatever that means) numbers of senior traditional leaders within his or her area of jurisdiction;

(b) his or her status is regarded and recognised in terms of customary law and customs as being higher than that of a senior traditional leader; and

(c) he or she has a customary structure to represent the traditional councils and senior traditional leaders that fall under his or her authority. ${ }^{8}$

If the government did not want claims by all and sundry, it should have said so and maybe formulated narrower criteria. But it has left the door wide open by establishing the Commission on Traditional Leadership Disputes and Claims, ${ }^{9}$ which may either on request or of its own accord investigate - "a case where there is doubt as to whether a kingship was established in accordance with customary law and custom". ${ }^{10}$ The wording implies that the Commission may investigate only when there is doubt. It cannot establish a kingship.

So where else does one look for other likely kingships? The other indicator is the existence of the title of paramount chief. Bennett ${ }^{11}$ describes paramount chieftainships as follows:

The indigenous polities of southern Africa could, broadly speaking, be divided into three tiers of authority: chief, wardhead and familyhead. The chief was the head of the hierarchy, although, in cases where a particular individual had gained primacy over his coevals, there might be an even higher authority. In these circumstances, the colonial powers were usually prepared to

7 DPLG Role of Traditional Leaders 22.

8 S 9(1)(b)(ii) of the Act.

9 S 22 of the Act.

$10 \mathrm{~S} 25(2)(\mathrm{a})(\mathrm{i})$ of the Act.

11 Bennett Customary Law 102. 
describe him as a 'king'. Sobhuza I, Mswati II, Shaka, Dingane and Moshoeshoe, for example, were all referred to as kings of their peoples. Otherwise, where central control was weaker (as with the Xhosa) or where the polity was simply not considered large enough (as with the Pedi), the principal rulers were described as 'paramount chiefs'.

This is a more rational description than that by some other authors, who state that they were called paramount chiefs only to distinguish them from the monarchs known in Europe. ${ }^{12}$

Section 22(7) of the Act enjoins the Commission:

...in terms of section 25(2) [to] investigate the position of paramountcies and paramount chiefs that had been established and recognised, and which were still in existence and recognised, before the commencement of this Act, before the Commission commences with any other investigation in terms of that section.

This presupposes that all of them constitute a claim or a dispute.

That sounds fair but the problem is in practice even more insoluble than that 'new' applications. The reason is that some paramount chiefs have been singled out for severe criticism as having been puppets of the apartheid regime. In some comments virtually all of them come under fire for playing ball with the apartheid government. Although some were not prepared to cooperate at all, the outcome of the manipulation of the system was a compliant cadre of traditional leaders who provided the personnel needed to realise an increasingly unpopular state policy. ${ }^{13}$ Without their compliance the establishment of the homelands would not have been possible.

It should therefore serve no purpose to go puppet-hunting after all these years, to find out which ones should be demoted or maybe dismissed altogether. The Department of Provincial and Local Government (DPLG) statement that colonial powers and the apartheid government introduced new and foreign 
levels of traditional leaders is no yardstick, really, for making only some of them kings or queens.

There is another route to a kingship. In terms of section 143(1)(b) of the Constitution of the Republic of South Africa 1996, a provincial constitution may provide for - "the institution, role, authority and status of a traditional monarch, where applicable".

One may safely assume that a traditional monarchy is the same as a kingship contemplated by the Act. It may, moreover, be assumed that the phrase "where applicable" envisages an existing kingship.

The legislature of KwaZulu-Natal published a draft constitution ${ }^{14}$ in which it is provided that -

(1) There is a Monarch for the Province of KwaZulu-Natal.

(2) The person currently holding office as the King of the Zulu nation, (the King of AmaZulu, the Ingoyama or Isilo) is, at the taking of effect of this Constitution, regarded as the Monarch for the Province of KwaZulu-Natal.

The Constitution has not yet been adopted. In the meantime the legislature went ahead and recognised Isilo as the Monarch of the Province. ${ }^{15}$ Isilo is defined as - "the Monarch for the Province of KwaZulu-Natal, as recognised in section 17 , or 'king' as defined in section 1 of the [Act]". ${ }^{16}$

The KwaZulu-Natal legislature has thus pre-empted an enquiry by the Commission. It may be inferred that any other province could also by-pass the Commission in this manner. Seen in this context section 143(1)(b) of the Constitution has become meaningless. The institution and other elements of a monarchy may be regulated by an ordinary provincial Act.

14 S 48(1) and (2) of the Draft Constitution of KwaZulu-Natal 2005.

15 S 17(1) of the KwaZulu-Natal Traditional Leadership and Governance Act 5 of 2005.

16 Ibid, s 1(1). 
Be that as it may, the question is: what is a kingship, the fact or the position of being a king? A king, including an African king, disposes of the following variables (by which I mean they may differ from case to case, but are present in some form or another):

\title{
2.1 Of the regal lineage
}

There are fairly well documented rules of succession, but they are by no means all there is to it. From earliest times African kings gained ascendancy and monarchial status by conquest of neighbouring communities. As explained by Sansom: ${ }^{17}$

\begin{abstract}
Independent chiefdoms were able to expand by the assimilation of relatively small groups of persons normally seen as 'refugees' from other tribes. But political expansion on the larger scale always involved a wider integration of established units - the jointure of chiefdoms to form larger political units, federations or kingdoms. Thus in Southern Africa, significant increases in the span of a ruler's command normally entailed the conquest or assimilation of constituent chiefdoms. The distinction between tribal federations and kingdoms depends on an assessment of the extent to which central control was established in a composite dominion.
\end{abstract}

The reasons for the existence of kingships must therefore be sought in history rather than in customary law and customs as dictated by section 9(1)(b)(ii)(bb) of the Act. In this regard the limitation imposed by section 25(4) of the Act is not clear. It provides that -

The Commission has authority to investigate all traditional leadership claims and disputes dating from 1 September 1927 [the date of coming into operation of the Black Administration Act].

It is admittedly qualified by section 25(2)(a)(vi) in terms of which relevant events that may have arisen before the said date may be considered where good grounds exist. One would have thought that all relevant historical events are important.

17 Sansom Traditional Leaders and their Realms 249.

$6 / 13$ 
Moreover, since the colonial and apartheid regimes started recognising traditional leaders, succession in some cases - in all too many, perhaps played second fiddle. The result was that "chiefs who were not amenable to state directives, no matter what traditional legitimacy they might have enjoyed, were ousted from office or passed over in matters of succession". ${ }^{18}$

While that is true one may ask: Does Parliament want the Commission to turn the clock back eighty years to 1927 , or even further to the colonial and Boer republican recognition of traditional leaders? This would be neither practical nor advisable. With reference to paramount chiefs, they are de facto and legally of a higher rank than chiefs (senior traditional leaders). Koyana ${ }^{19}$ shows convincingly that the notion that 'hereditary' is the sole criterion is a misconception. Recognition and appointment have by statutory and judicial decrees become the decisive factors. When a chief has been recognised he becomes a chief for all intents and purposes.

The Act contains no provisions for demotion or dismissal. Depriving chiefs of their status would create disorder, because all of them have a larger or smaller component of senior traditional leaders within their domains for a long time.

Section 12(1) of the Act provides for the removal of a king or queen on certain listed grounds. The grounds obviously do not cover a finding by a Commission, unless the finding could be interpreted as a finding that the incumbent was wrongfully appointed or recognised as envisaged by section 10(1)(c) of the Act. The defence would be that it was not wrongful at the time of appointment or recognition.

\subsection{Rights over land}

The next component of kingship is their possession of rights over land - not in the sense of tenure, but as a domain, a sphere of control or influence. Some of the domains were made up of subordinate chieftainships, but all of them were 
within the scope of the king's commands. ${ }^{20}$ The colonial and apartheid regimes defined these areas. For homeland purposes the apartheid government established regional authorities with paramount chiefs at the apex. If, say, any two paramount chieftainships should be combined into one kingship, would the different communities accept a common status as subjects who could be commanded by [the] king ${ }^{21}$ Would the paramount chiefs thus 'deposed' accept the decision?

\subsection{Political power}

The third of the main features of kingship is that the kings should command political power.

Their role in local politics is still as of old. They are the fathers of the nation, the chief priests, the judges, the rainmakers (in some cases), and so on. They are endowed with the ability to ensure the prosperity and well-being of their people. $^{22}$ I am sure that on that score traditional leaders are still respected, even venerated, by their followers. A change in status or deposition would mean that the followers would have to shift their allegiance to another leader. This is the inevitable result of disestablishing structures that were created by apartheid and homeland legislation.

As it is, some chiefdoms and kingdoms are not homogenous. The National Party grouped some disparate communities (tribes) within paramountcies, or what they called ethnic units. Jackson, ${ }^{23}$ for example, lists no less than 17 communities of non-Thembu origin that willy-nilly "fall under" the Senior Thembu, some under the Emigrant (Western) Thembu, and some again under neither. There are numerous other similar situations. Such situations create conflicts. The Commission will have to reconsider all of these (some of which are in the domains of senior traditional leaders) to ascertain whether they do in fact (of course no longer as the factotums of homelands) fall under one king or

20 Sansom Traditional Leaders and their Realms 249.

21 Ibid.

22 Mönnig The Pedi 252.

23 Jackson Ethnic Composition. 
another. Some groups will probably grab the opportunity to claim independence from whichever paramount chief into whose domain they were engineered.

\subsection{The ethnic factor}

If the recognition of kings and queens is not done on the basis of fundamental principles, it may resuscitate the debate and generate conflicts about ethnic identity. Contestants will no doubt play their own ethnic cards on origin, religion, culture and language, to outbid their opponents. Skweyiya ${ }^{24}$ warns that -

Such conflict should be avoided by all means. In such situations traditional leaders will try by all means to manipulate ethnic consciousness (and) will capitalise on certain culture-bound factors that support traditionalism (and) also specifically manipulate such things as local myth, ritual, symbol and customary law.

Skweyiya pleads that a great deal of research is needed into what he calls "the need to diffuse ethnicity". I am afraid the Act's version of a traditional community (tribe) is no better than the colonial-apartheid recognition of tribes. All it says is that a community may be recognised if it -

(a) is subject to a system of traditional leadership in terms of that community's customs; and

(b) observes a system of customary law. ${ }^{25}$

The apartheid obsession with ethnic nation-states is still all too fresh in our memories. The apartheid government propagated with all the means at its disposal -

that the pre-colonial African population in southern Africa consisted of a number of discrete cultural-linguistic-political units and that these units have continued, unchanged into the present. These 'tribes' it is further assumed, coincide with the modern 'nations' Swazi, Zulu, Xhosa, Venda. Tswana, Ndebele, etc. - associated with the various 'national states' within South Africa. ${ }^{26}$ 
Another sensitive issue is that there is an urban-rural divide and an intermingling of people from different communities. Some may feel ill at ease, and even object, if they are categorised as belonging to a particular ethnic group or as "falling under" a recognised king.

\section{Conclusion}

Given the colonial and apartheid past, it was inevitable that something be done about traditional leaders. But the proposal to revamp the institution by the creation of kingships in this manner is a recipe for disaster. There is no objection against calling a king or a paramount chief a king, but the proposed process is flawed. It could also cost the government millions to keep a Commission in office until all the claims and disputes are resolved. In so far as they don't accommodate claimants, its findings will lead to endless appeals and reviews, in which judges in different jurisdictions may make divergent findings.

In my view the DPLG should go back to the drawing board. It should determine clearly what it wants to achieve and how, in a more straightforward and costeffective manner. It has misconstrued the issue and piloted a law, to say it as politely as possible, which is inept.

Although its policy was ill-conceived, the apartheid regime formulated it with meticulous accuracy and carried it out with military precision. Now, after the demise of apartheid, a Commission operating independently from government is supposed to rectify those wrongs under the banner of resolving disputes and claims, and to do so within a time frame of five years. It cannot succeed, in five or any other number of years, unless its task and the envisaged method of implementation are more clearly formulated.

Lastly, I submit that it is incorrect for the DPLG, the Premiers and the State President to stand on the sidelines, expecting the Commission to take 
responsibility. Note that the State President must immediately implement the Commission's findings. ${ }^{27}$ What if he feels that he cannot live with the consequences? There is nothing in the Act to oblige the Commission to take the likely consequences of its resolutions into account, nor to take counsel with the office-bearers concerned. 


\section{Bibliography}

Bennett The Constitutional Base

Bennett TW The Constitutional Base of Traditional Rulers in South Africa in d'Engelbronner-Kolff FM, Hinz MO and Sindano JL (eds) Traditional Authority and Democracy in Southern Africa (Windhoek Centre for Applied Legal Studies University of Namibia 1998)

Bennett Customary Law

Bennett TW Customary Law in South Africa (Juta Cape Town 2004)

DPLG Role of Traditional Leaders

Department of Provincial and Local Government The Role of Traditional Leaders in Governance: A Consolidated Set of Policy Instruments (DPLG Pretoria 2004)

Jackson Ethnic Composition Jackson HO The Ethnic Composition of the Ciskei and Transkei (Government Printer Pretoria 1975)

Koyana 2002 Speculum Juris

Koyana DS "Chieftainship and headmanship are not hereditary" 2002 Speculum Juris 144-160

Mönnig The Pedi

Mönnig HO The Pedi (Van Schaik Pretoria 1967)

Oomen 2000 African Studies

Oomen B "We must go back to our history: Retraditionalisation in a Northern Province Chieftaincy" 2000 (59) African Studies 71-95

Parker and Tommy "Traditional Leadership"

Parker IM and Tommy JL "Traditional Leadership" (Unpublished research report on traditional systems of administration and their role in the 
promotion of good governance of the Institute for Local Governance and Development Traditional Leadership in Africa undated)

Sansom Traditional Leaders and their Realms

Sansom B Traditional Leaders and their Realms in Hammond-Tooke WD (ed) The Bantu-speaking Peoples of Southern Africa (Routledge \& Keegan Paul London 1974)

Skalnik Tribe as Political Category

Skalnik P "Tribe as Political Category" in Boonzaaier E and Sharp J (eds) South African Keywords: The Uses \& Abuses of Political Concepts (David Philips Cape Town 1988)

Skweyiya Chieftancy

Skweyiya Z Chieftancy, the Ethnic Question and the Democratisation Process in South Africa Occasional Paper Series (UWC Community Law Centre Cape Town 1993)

\section{Register of legislation}

Black Administration Act 38 of 1927

Constitution of the Republic of South Africa 1996

Draft Constitution of KwaZulu-Natal 2004

KwaZulu-Natal Traditional Leadership and Governance Act 5 of 2005

Traditional Leadership and Governance Framework Act 41 of 2003 